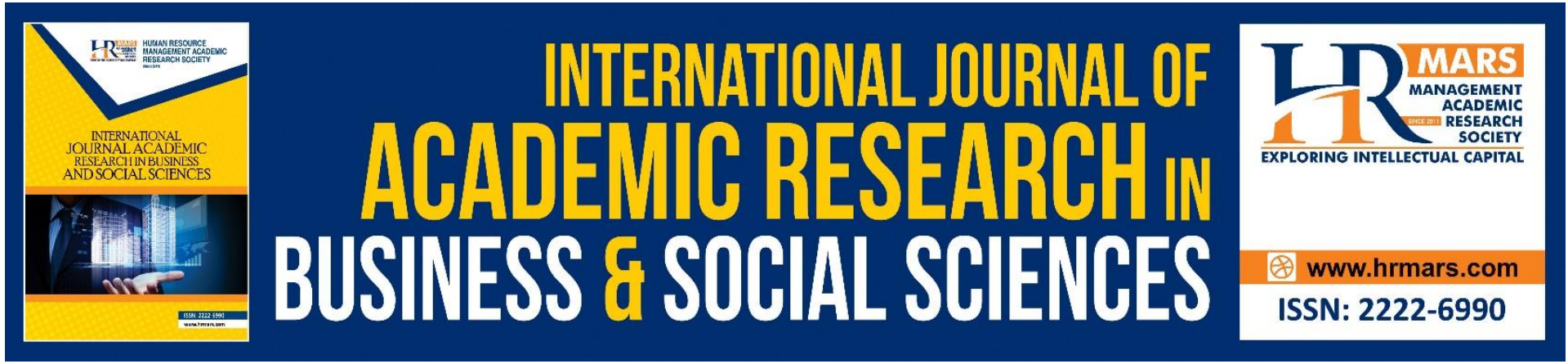

\title{
Use of Local Labour in Oil Palm Agriculture
}

\author{
Suhana Saad, Zaimah, R. \& Novel Lyndon
}

To Link this Article: http://dx.doi.org/10.6007/IJARBSS/v11-i9/10992

DOI:10.6007/IJARBSS/v11-i9/10992

Received: 08 July 2021, Revised: 10 August 2021, Accepted: 30 August 2021

Published Online: 11 September 2021

In-Text Citation: (Saad et al., 2021)

To Cite this Article: Saad, S., Zaimah, R., \& Lyndon, N. (2021). Use of Local Labour in Oil Palm Agriculture. International Journal of Academic Research in Business and Social Sciences, 11(9), 205-215.

Copyright: (c) 2021 The Author(s)

Published by Human Resource Management Academic Research Society (www.hrmars.com)

This article is published under the Creative Commons Attribution (CC BY 4.0) license. Anyone may reproduce, distribute, translate and create derivative works of this article (for both commercial and non-commercial purposes), subject to full attribution to the original publication and authors. The full terms of this license may be seen at: http://creativecommons.org/licences/by/4.0/legalcode

Vol. 11, No. 9, 2021, Pg. 205 - 215

Full Terms \& Conditions of access and use can be found at http://hrmars.com/index.php/pages/detail/publication-ethics 


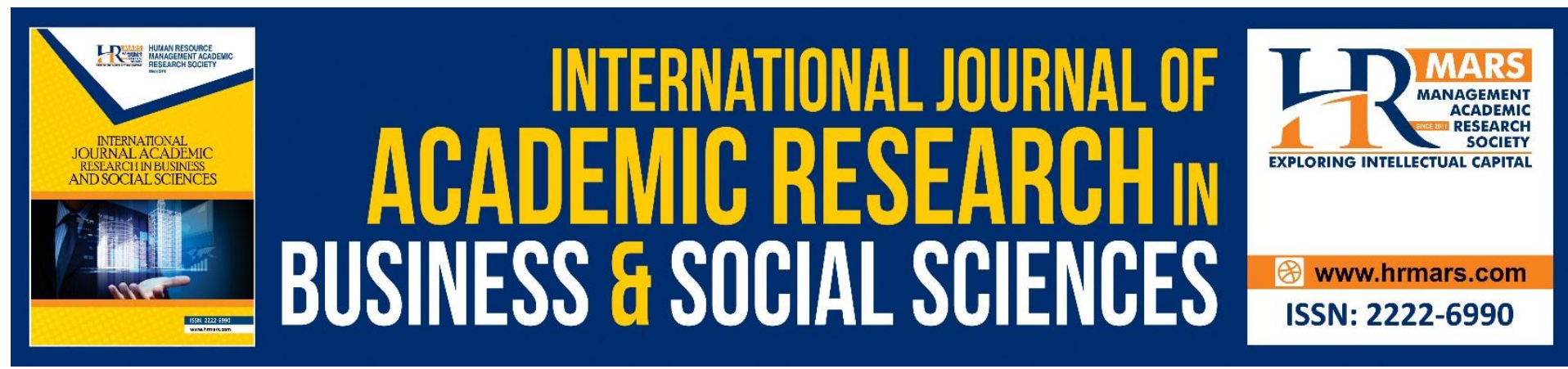

\title{
Use of Local Labour in Oil palm Agriculture
}

\author{
Suhana Saad, Zaimah, R. \& Novel Lyndon \\ School of Development, Social \& Environmental Studies \\ Faculty of Social Sciences \& Humanities, Universiti Kebangsaan Malaysia
}

\begin{abstract}
The Covid-19 pandemic has had a great impact on the palm oil industry in Malaysia. This includes the issue of retrenchment of foreign workers. Sarawak is the main oil palm cultivation state in Malaysia which is affected by this problem. The land area is vast but faces the problem of labour shortage. Retrenched foreign workers will be replaced by local labour. However, the average local is less interested in working in this industry. Most smallholders prefer to use imported labour which is considered more productive. Therefore, this study aims to identify some strategies to increase local labour utilization in oil palm agriculture in Sarawak. Due to the Covid-19 pandemic, the country has stopped the recruitment of new foreign workers entering to work in Sarawak since March 2020. This study uses a qualitative method in conducting research on local labour and the strategies to increase local labour utilization in oil palm agriculture in Sarawak. The results show that among the strategies that can be used currently are, to get the local community involved, increase the level of mechanization, raising the minimum wage, youth Involvement, and empower the training centre. The implication of this study is that stakeholders in Sarawak can take immediate steps to ensure that oil palm production is not severely affected.
\end{abstract}

Keyword: Oil Palm, Covid 19 Pandemic, Local Labour, Productivity, Smallholders

\section{Introduction}

Dependency on foreign workers in the agricultural sector is due to lack of interest among the community, low wages and social status. Some strategies are needed to encourage the use of local labour, especially when the country is hit by the Covid19 pandemic. However, the lack of interest of locals to get involved in the agricultural sector will also affect the productivity of crops when they have to work on farms. In Sarawak, dependence on labour is categorized into several types: Imported labour, family labour, village labour, seasonal labour/invisible labour. How to manage this multi-category labour depends on effective leadership. Leadership in previous studies was closely related to increased productivity.

Meanwhile, through the Sarawak Labour Ordinance 1952, it is stated that an employee is a person who has signed a service contract with an employer and earns a salary not exceeding RM2, 500 per month and a person regardless of his salary earned with an employer and works as a manual labourer, working in operation or maintenance, motor vehicles i.e. for transportation or trade. This definition is more relevant in the context of legislation, especially in this country and it provide a concrete explanation in terms of its meaning in a more comprehensive way. 
Further, the Department of Statistics Malaysia (2020) states that employees are covered by all persons employed in December or during the last pay period during the reference year. This provides a more general statement regarding the definition of employee or labourer. Local workers are fundamentally directed to groups or individuals who are recognized as citizens who work with any employer in the country. Due to the Covid-19 pandemic, the country has stopped new foreign workers entering Sarawak since March 2020 and thus has aggravated the already acute shortage of workers situation here rendering the industry to heading towards an almost certain business closure for most plantation businesses, big or small which are now crippled by the severity of this critical worker shortages. This situation has caused hardships and sufferings to the local plantations' operators especially during this economic crisis caused by the Covid 19 pandemic (SOPPOA, 2020). Every company in the Sarawak palm oil industry would prefer to hire locals for the jobs if there are workers available (The Borneo Post).

This study aims to identify some strategies to increase local labour utilization in oil palm agriculture in Sarawak. The study uses a qualitative method in conducting research on the content of scholars' research on local labour and the strategies to increase local labour utilization in oil palm agriculture in Sarawak.

\section{Local Labour}

In general, in the definition of labour, the worker is the universal individual whichever is most needed, depending on the content in its explanation. According to the International Labour Organization (2003), labour is referred to as all persons of working age who supply labour for the production of goods and services during a specified reference period. This statement is a global and referred to various countries around the world. Whereas in the Malaysian context, based on the perspective of the Employment Act 1955 which shows that the workers of each labour are any person or group that belongs to any category in the First Schedule which is in it. This category is divided into two categories of contents of the first category of employees classified according to the required wages of up to RM 2,000 per month and the second category has classified the type of work performed requires payment of salary of RM 2,000, employees involved in any work, supervising employees and employees involved in shipping related duties.

Fundamentally, the phrase local labour is often the subject of discussions on the issue of labour shortages, especially in the national economic sector. According to Surianshah et al. (2020), the shortage of local labour is often associated with the oil palm plantation sector, which will be the main thrust in the discussion of this study as a whole in the explanation related to the problems raised. This sector is categorized in the agricultural industry which is used as a second choice by the local community in finding employment compared to other sectors such as the manufacturing and government sector (Saad et, al. 2016). This situation is often associated with low wage problems, difficulties in career development, difficult rural life, and 3D sector jobs i.e. difficult, dirty, and dangerous (Kamaruddin et al. 2018). So it is not surprising that statistics show that in 2013 alone, as much as 69 per cent of the total oil palm plantation workers in the country are foreign nationals (Abdullah et al., 2016).

\section{Scenario of Local Labour in Agriculture}

The agricultural sector globally and nationally has undergone some changes that have sparked new issues and challenges. Among them is the issue of the labour force in this sector which is often discussed because it is still labour intensive. According to Abdullah et al. (2016), the 
agricultural industry is a labour-intensive industry, especially for the oil palm plantation sector. The participation of local workers in the agricultural sector is less encouraging than other sectors although this sector offers wider employment opportunities. This sector is seen as less focused by local youths to find employment because they are more interested in working in other sectors, especially under the category of the public sector which can provide opportunities for brighter and more stable career development (Yoon, 2018). Malaysia and even foreign countries are experiencing the same situation.

The involvement of local or family workers occurs due to several factors that motivate them to venture into the agricultural sector. Therefore, some of the factors that influence the decision of local people to venture into the agricultural industry, especially in the plantation sector are negative perceptions, environmental and occupational safety factors as well as lack of knowledge. According to Ayob et al (2015), low wages are among the reasons local youths are not involved in the plantation industry in particular.

Globally around the $80 \mathrm{~s}$ and $90 \mathrm{~s}$, the agricultural sector has grown where rural Pakistan developed its agriculture. It is explained through a study conducted by Afzar and Nasir (1987) in the country which focuses on the aspects of the use of women labour in the agricultural sector. The results of this study comprehensively show that a large number of these women workers have directly contributed to agricultural output, household income and local economic activities. Besides, the employment rate of women has recorded a continuous increase due to the social, economic and cultural changes that have taken place in the country due to the development programs implemented. This study generally explains the influence of women's involvement which is one of the determining factors to the development of the agricultural sector in the country.

Next, a study conducted by Faridi and Basit (2011) in the same country related to the rural agricultural sector, which is more focused on exploring the factors that determine the participation of the local labour market. The results of this study show that education, the Economic Capital Index, and the Social Capital Index have a significant impact on the supply of rural labour in the agricultural sector. Also, the number of livestock and land tenure measures had a significant impact on rural labour force participation. Researchers have also given some suggestions for improvement to further increase labour productivity in agriculture such as basic and higher education institutions should be established in rural areas especially agricultural education and the government should improve rural infrastructure by providing electricity, health facilities and road infrastructure to improve quality of life of the population. This is important to maintain agriculture manpower resources.

In addition, a subject-based study conducted in Abia, Nigeria by Agwu et al (2004) which is more focused on youth participation in agriculture in the country found that various factors drive the involvement of local youth labour in the agricultural sector. Estimates that determine the participation of agricultural labour among youths in the study area show that respondents' education, income from non-agricultural sources, parental employment, paternal education, farm measurement and mechanization rate influence labour participation among youths in Abia State, Nigeria. However, the use of youth labour in agriculture is seen to be still at a low level because the issue of rural development has resulted in shortages in increasing agricultural productivity. This is because rural development is at the heart of the country's economic development and it provides other employment opportunities to the rural population which can increase their income. The ongoing rural development has provided the necessary facilities such as better housing, paved roads, health, and education services, better socio-economic infrastructure. This improvement in 
the socio-economic quality of the rural population has allowed the youths to work in other sectors instead of choosing to work in the agricultural sector due to lower income compared to other sectors.

Studies related to factors influencing labour force involvement were also conducted by Barbara et al (2013) which focuses on European countries. Through the study conducted, it was found that the factors that influence the involvement of labour in the agricultural sector in Europe are the factors of age, level of education, gender and family background. The results show that individuals over the age of 45 to over 55 with lower levels of formal education or training (except for those with special agricultural or veterinary education) are mainly selfemployed as well as family workers and women with children, more likely to engage in agriculture. Employment opportunities in the agricultural sector are higher in terms of farm characteristics, and area of farmland as well as livestock production. Thus, the theory of human capital and the life cycle is the most influential explanation for understanding the mobility of agricultural labour (Rizov and Swinnen, 2004).

Furthermore, in the context of Malaysia, several studies also touch on the topics focused, including the study conducted by Surianshah et al (2020) which emphasizes the factors of youth involvement in the country to engage in the oil palm plantation sector in particular based on their demographic factors. The results of the study found that factors such as gender, race, place of residence, experience, and involvement of family members in the oil palm plantation sector are contributing factors to the availability of local youths in the country to engage in this sector. This study also suggests several things to be improved in attracting local youths, especially to venture into the oil palm agriculture industry, among others are concerning wages, benefits, work environment and safety aspects in the workplace.

Meanwhile, a study conducted by Fuad and Sarina (2014) focussed on the impact of the influx of foreign workers, especially from Indonesia to this country on the economic industry environment. In general, the study looked from the perspective of foreign labour which gives a very significant influence on the participation of local workers in the country. Motivational factors such as economic pressure and poverty are the main causes of their influx resulting in a huge impact on local labour in the country. Next is a study conducted by Kamaruddin and Norehan (2018) which looked from the perspective of the level of job satisfaction among youth workers in Malaysia in the oil palm plantation sector. The results found that government and employer policies related to the aspects of profit offered to employees are the most dominant factor in influencing their enjoyment of work in this industry, while perception factors related to employment status and work environment are factors that put pressure on workers comfort in this industry.

Overall, it can be clarified in more detail that there are key factors that should be emphasized in looking at the involvement of local labour in the agricultural sector, especially involving the oil palm plantation industry in the country. These factors include educational factors, demographics and policies implemented by the government in attracting local workers to be the main driver for the community to get involved in the oil palm plantation industry in particular. The issue of the influx of foreign labour in this sector should also be taken seriously which indirectly is an important indicator in influencing the involvement of local labour in the industry. These matters should be refined to encourage the participation of local labour in helping the country increase the productivity of this sector which is highly dependent on the labour force to drive the processes related to this industry. 


\section{Oil Palm Agriculture in Sarawak}

Malaysia on average allots one worker for every 8 hectares, but the MPOA (Malaysian Palm Oil Association) wants a "quantum leap" in technology that would double the land area for each worker to 16 hectares. This would reduce reliance on labour, which accounts for around 30 per cent of production costs (Channel News Asia, 2020). The industry fears the labour crunch will hurt palm oil production this year by delaying the harvest of perishable fruit, giving an edge to bigger rival Indonesia which has no such labour problems. Travel and movement restrictions have left the world's second-largest palm oil producer grappling with a shortage of 37,000 workers, nearly 10 per cent of the total workforce (Channel News Asia, 2020).

In 2019, the size of the planted area for oil palm in Sarawak was approximately 1.59 million hectares. Most of the palm oil plantations in Malaysia was found on Peninsular Malaysia, followed by Sarawak and then Sabah. Malaysia is the world's second-largest producer and exporter of palm oil (Hirschmann, 2021). There are a total of 40,513 oil palm smallholders in Sarawak, covering 234,812ha, with 59.2\% of them being Malaysian Sustainable Palm Oil certified. However, the plantation sector and smallholders in Sarawak are still heavily dependent on foreign workers instead of machinery to harvest the fruits efficiently (Free Malaysia Today, 2021).

According to Sarawak Oil Palm Plantation Owners' Association (SOPPOA), the palm oil industry in the state "is critically short of workers". Even before the Covid-19 pandemic, plantations were already suffering from labour shortage. The shortage is estimated at more than 45,000 (Vietnam, 2021). Therefore, several strategies need to be considered to ensure the sustainability of this industry in Sarawak.

\section{Strategies to Increase the Use of Local Labour in the Oil Palm Agriculture in Sarawak}

In Malaysia, the issue that is often associated with the oil palm plantation sector is the issue of labour shortage, especially local labour itself. Lack of manpower in oil palm plantations causes the harvest to be delayed and to curb production. The labour force in the oil palm plantation sector is more dominated by foreign workers than local workers. Therefore, it is important to increase local labour involvement to reduce dependence on foreign workers. However, to increase the participation of the local community in the oil palm plantation sector is a hurdle as this group is seen as less interested in working in the oil palm plantation sector even though this sector provides better employment opportunities. This situation makes it difficult for employers to get local labour to work in the plantation sector.

\section{Participation of Local Community}

The participation of local communities in the oil palm plantation sector is not encouraging compared to other sectors where this sector is in the category in the agricultural industry and is used as a second choice by the community in finding employment compared to other sectors such as manufacturing and government sector (Saad et al. 2016). According to Abdullah et al. (2016), the agricultural industry is a labour-intensive industry, especially for the oil palm plantation sector. The oil palm plantation sector often suffers from labour shortages, especially local labour. In 2012, the country's oil palm sector experienced a shortage of workers due to many Indonesian workers starting to leave Malaysia when the oil palm sector there grew rapidly and offered higher minimum wages than wages in Malaysia. This situation caused the country's oil palm plantation sector to experience a shortage of manpower needed. 
In 2013, 69 per cent of the total oil palm plantation workers were foreigners, while the rest were local workers (Abdullah et al. 2016). Therefore, the best way to address the issue of local labour shortage in the sector is with the active involvement of the government and farmers themselves to increase the use of local labour in the oil palm agriculture sector. If you look at the efforts put in by the government in boosting efforts to attract the participation of local workers in the oil palm agriculture sector, there are many initiatives in the aspects of education, finance, technical and administration. Through technical aspects, the government has encouraged the use of mechanization (increase utilization of mechanization) as one of the solutions to increase the participation of local labour and reduce dependence on foreign labour is through mechanization especially for harvesting and collecting Fresh Fruit Bunches (TBS) because this mechanization has proven to increase employee productivity and thus reduce the need for substantial labour.

\section{Increase the Level of Mechanization}

Furthermore, although the government has encouraged agricultural land owners to increase the level of mechanization used especially for harvesting activities and collection of fresh fruit bunches (TBS), the level of mechanization so far is still seen at a low rate. This matter should be further strengthened for the sake of continuity in increasing labour productivity in the country, especially in oil palm plantation activities. Apart from that, efforts through the empowerment of technical aspects are also intensified in the harvesting stage where the Malaysian Oil palm Board (MPOB) has introduced Cantas techniques which have been proven to increase productivity to 2.5 tons per day and this reduces labour consumption by around 50 per cent in an area oil palm farming. To encourage oil palm owners to use Cantas technique, MPOB has lent a total of 1027 Cantas to selected companies as well as fresh fruit bunch (TBS) traders (Azman Ismail 2013). The government's efforts are like a double-edged sword because it can reduce dependence on labour, especially foreign labour through this mechanization as well as open wide opportunities for local people to work in oil palm agriculture. After all, there is no more competition with foreign labour.

\section{Raising the Minimum Wage}

Besides, the strategy implemented by the government to increase the use of local labour is through the financial aspect by raising the minimum wage to encourage locals to work on plantations, especially in oil palm plantations. If you look at 2013, the Malaysian government has implemented the initiative to increase the minimum wage of RM 900 per month for workers in Peninsular Malaysia and RM 800 per month for those in the states of Sabah and Sarawak. The implementation of this minimum wage initiative is again implemented by the government when announcing the new minimum wage level in 2019 which is RM 1100 per month based on payment according to the quantity or productivity and quality of work done within 8 hours of work a day or more. The Department of Industrial Relations Malaysia under the Ministry of Human Resources has also implemented a productivity-linked wage system (PLWS). This wage system includes a combination of monthly income and other frequently paid payments, annual salary increases, annual bonuses or other cash payments to employees. These include advertising for locals to fill vacancies to ensure that local jobseekers are given priority for employment, while the company must have a minimum paid-up capital of RM1mil, proper land lease documents from the state government and valid licences from the Malaysian Palm Oil Board (MPOB) (Soppoa, 2015). 
Wage incentives implemented by the government are expected to attract locals to participate in jobs in the oil palm agriculture sector. Although the plantation sector provides wider employment opportunities with salary and benefits initiatives comparable to other sectors, this sector is still not strong enough to attract locals to participate. This is because working in the plantation sector such as oil palm is often associated with perceptions related to the problem of low wages and this is a factor that influences the decision of local people to venture into the agricultural industry, especially in the plantation sector (Kamaruddin et. Al 2018). Therefore, to attract interest and increase the involvement of local people in the national oil palm plantation, Jusoh et al. (2017) argue that preparations from an early stage should be implemented to provide exposure to the importance of the oil palm industry.

\section{Youth Involvement}

Exposure to the importance and awareness of the younger generation of career opportunities available in this field should be provided at the school level. This will increase the interest of the younger generation to venture into the oil palm plantation sector in the future can directly change the negative perception of this industry. The Sarawak Oil Palm Plantation Owners Association (Soppoa) said, the labour shortage issue has been plaguing the state's palm oil industry for years (The Borneo Post). This is also supported by Saad et al. (2016) related to exposure and education on oil palm plantations given at an early stage can generate ideas from the younger generation to innovate in the agricultural industry by adapting the use of more advanced technology. Educational and administrative aspects are often related to the use and development of technological aspects. Along with current developments, agricultural studies are also emphasized by the government through the offering of formal programs under the Ministry of Agriculture and Agro-based Industry and also the Ministry of Higher Education (MOHE) Malaysia. Agricultural studies in institutions of higher learning under the MOHE are to meet the demand for skilled and trained human resources in the country's agricultural sector (Ministry of Higher Education Malaysia 2010). In principle, programs and activities of teaching and learning agricultural knowledge for the needs of the country are jointly planned by institutions of higher learning, Ministry of Higher Education Malaysia, Ministry of Agriculture and Agro-based Industry and Public Service Department with the cooperation and feedback from agro-based industries. The field of agriculture covers a wide range of skills in the field of skills as well as the development and progress achieved in this field is also quite encouraging but less involvement from the local youths. Thus, HEls as a centre for learning and generation of technology and innovation have a responsibility in achieving the goals of the plan through teaching and learning activities, research and professional services. This is expected to provide a positive perception development in increasing the involvement of local communities specifically in oil palm plantation activities in the country. Also, the Malaysian Oil palm Board (MPOB) has submitted a proposal to the government to offer specific incentives to local workers to participate in the oil palm plantation sector which is now dominated by foreign workers. The initial action plan to be refined by the government is submitted in line to reduce dependence on foreign workers in the commodity in the future.

\section{The Empowerment of Training Centre}

Therefore, this initial step is important in preparation to avoid the occurrence of operational problems in the plantation sector if the reduction of foreign workers occurs either due to government measures or the transfer of manpower to other countries. Therefore, to ensure 
the participation of more locals in the oil palm plantation sector, MPOB intends to strengthen the courses offered by the Oil palm Training Center (Plasma) in Keratong, Pahang and Lahad Datu, Sabah. The empowerment of the training centre will be the focus of MPOB to open space to produce more locals with the status of skilled workers in the sector and enable locals to enjoy incentives when participating in farm mechanization operations courses offered under Plasma. Therefore, training for Malaysians, especially the young, is very important to make them trained workers and can be used as a backup to reduce dependency on foreign workers in the oil palm agriculture sector. Empowerment through the aspects described including technical, financial, educational and administrative aspects is seen as a benchmark to efforts in prospering this sector to be the main choice of the local community to develop a career in their work.

Palm oil coming under fire on the global stage, investment in sustainable planting and harvesting is more important than ever. MPOB asserts that the new variety is an important development in response to labour shortages and limited land availability. Beyond government investment in the agricultural sector, the industry must look inward to increase the economic feasibility of adopting technology and good agricultural practices. These goals are representative of progress for which Malaysia must strive, not only for the productivity of the plantation industry, but also for the country's continued economic development. Malaysia has affirmed its support of the United Nation's Sustainable Development Goals (SDGs), most recently through the Shared Prosperity Vision 2030, and the agricultural sector provides ample opportunities for progress in the realms of both economic and environmental sustainability (Crowley, 2020).

\section{Conclusion}

The issue of shortage of local labour in the agricultural sector is not only a problem for the state of Sarawak but is a national issue. However, the most affected is the state of Sarawak which is one of the largest contributors of oil palm in the country. The problem of labour shortage in Sarawak has been going on since before the Covid-19 pandemic began. The situation worsened when, foreign workers had to be laid off. To address this problem, local labour had to be brought in to work in the oil palm plantations. There are some strategies to increase the use of local labour in the oil palm agriculture in Sarawak such as participation of local community, increase the level of mechanization, raising the minimum wage, youth involvement and the empowerment of training centre. The implication of this study is that stakeholders in Sarawak can take immediate steps to ensure that oil palm production is not severely affected.

\section{Ackowledgement}

This research is funded under the grant EP-2020-036.

\section{Referencess}

Abdul Razak J., Rizal, M. A., Ikmal, M. H., Yosri G., Zahara, M., Syahmin S., Asyraf, A., Azwan, B., Amirulrashid, M., Borhan, S., Azman I., Solah D., Rahim, S., Norman, K., \& Kushairi, A. (2017). Development and Evaluation of New generation oil palm motorised cutter (Cantas Evo). Journal of Oil palm Research : 1-13.

Abdullah, N., Ahmad, S. A., \& Ayob, M. A. (2016). Labour force participation of rural youth in plantation sector of North Peninsular Malaysia. Journal Ekonomi Malaysia 50(2): 83-92. 
Afzal, M., \& Nasir, Z. M. (1987). Is female Labour force participation really low and decliningin Pakistan? A look at alternative Data Source. The Pakistan Development Review Vol XXVI(4): 700-709.

Agwu, N. M., Nwankwo, E. E., \& Anyanwu, C. I. (2014). Determinants of Agricultural labour participation among youths in Abia State, Nigeria. International Journal of Food and Agricultural Economics Vol 2(1): 157-164.

Ayob, M. A., Abdullah, N., Ali, J., \& Kamaruddin, R. (2015). Perception of local youth in Sabah towards career in oil palm plantation. Asia Pacific Journal of Advanced Business and Social Studies 1(1): 239-246.

Ismail, A. (2013). The Effect of Labour Shortage in the Supply and demand of oil palm in Malaysia. Oil palm Industry Journal Vol 13(2): 15-25.

Barbara, T., Alastair, B., \& Sophia, D. 2013. Determinants to leave agriculture and change occupational sector: Evidence from an Enlerged EU. Factor Markets Working Paper 46: $1-22$.

Bill Rosenberg. (2010). Real Wages and Productivity in New Zealand. Working paper. Labour, Employment and Work in New Zealand. New Zealand Council of Trade Unions Te Kauae Kaimahi Wellington 2010.

Crowley, M. Z. (2020). Foreign Labor Shortages in the Malaysian Palm Oil Industry: Impacts and Recommendations. Asian Journal of Agriculture and Development, 17(2): 1-17. https://doi.org/10.37801/ajad2020.17.2.1).

Channel News Asia. (2020). COVID-19 pandemic forces Malaysian palm industry to rethink reliance on foreign labour.

https://www.channelnewsasia.com/news/asia/covid-19-malaysia-palm-oil-industrylocal-foreign-labour-13030166.

Department Statistics of Malaysia. (2020). Guna tenaga, Produktiviti dan Upah: Newsletter. https://www.dosm.gov.my/v1/uploads/files/6_Newsletter/Newsletter\%202020/DOS

M_MBLS_3-2020_Siri-41.pdf [04 February 2021].Employment Act1955 (Malaysia)Faridi, M. Z., \& Basit, A. B. (2011). Factors determining rural labour supply: A micro analysis. Pakistan Economic and Social Review Vol 49(1): 91-108.

Fuad, M. B., \& Sarina S. N. (2015). Buruh Indonesia di Tawau, Sabah: Satu Kajian Kes. Prosiding Economics and Finance, Simposium Ekonomi, Kewangan dan Perbankan, SEFB 2014, hlm, 1-10.

Free Malaysia Today. (2021). Sarawak falls short on palm oil despite having largest plantation area.https://www.freemalaysiatoday.com/category/nation/2021/03/29/sarawak-fallsshort-on-oil-palm-despite-having-largest-plantation-area/.

Gratton, L., \& Ghoshal, S. (2003). Managing Personal Human Capital: New Ethos for the 'Volunteer'Employee. European Management Journal 21(1): 1-10.

Hasami, H. (2013). Tingkat Produktiviti Buruh dan Kadar Pengangguran dalam Pembangunan Ekonomi Wilayah Pantai Timur (ECER). Prosiding PERKEM VIII, Jilid 2, hlm. 850860.

Hirschmann, R. (2021). Areas planted for oil palm Sarawak, Malaysia 2010-2019. file://C:/Users/User/Desktop/•\%20Malaysia_\%20oil\%20palm\%20total\%20planted\%2 Oareas\%20in\%20Sarawak\%20_\%20Statista.html.

International Labour Organization. (2003). ILO Glossary of Statistical Terms. https://www.ilo.org/ilostat-files/Documents/Statistical\%20Glossary.pdf [04 February 2021]. 
Jusoh, M. A., Omar, A. R. C., \& Ahmad, A. (2017). Tahap pengetahuan pelajar dalam industri sawit di Malaysia. Management Research Journal, 7(1): 154-162.

Kamaruddin, R., Abdullah, N., \& Ayob, M. A. (2018). Determinants of jobs satisfaction among Malaysian youth working in the oil palm plantation sector. Journal of Agribusiness in Developing and Emerging Economies 8(4): 678-692.

Kementerian Pengajian Tinggi. (2010). Hala Tuju bidang Pertanian. Shah Alam: Penerbit Universiti Teknologi MARA.

Lembaga Minya Sawit Malaysia (MPOB). (2021). Pusat Tunas, Malaysian Oil palm Board. http://palmoilpedia.mpob.gov.my/pusat-tunas-mpob/ [02 Febuari 2021].

Halib, M. (2004). Peranan Tanaman Padi Dalam Pembangunan Di Malaysia : AnalisisSejarah Dan Kontemporari. Journal of Southeast Asian studies Vol 9:189-212.

Zainuddin, M. Z. (2020). MPOB cadang insentif tarik pekerja tempatan ke lading sawit. Berita Harian Online, 24 Ogos:1.

Nailah, H., Noorsiah, S., \& Abu Hassan, M. D. (2011). Upah dan Produktiviti Buruh: Satu Analisis dalam sector Pembuatan. Prosiding PERKEM VI, Jilid 2, hlm. 319-331. Palazuelos, E,. \& Fernandez, R. 2001. Demand, employment, and labour productivity in the European economies. Structural Change and Economic Dynamics Volume 20 (1): 1-15.

Roslina, K., \& Norehan, A. (2018). Determinants of job satisfication among Malaysian youth working in the oil palm plantation sector. Journal of Agribusiness in Developing and Emerging Economies Vol 8 (4): 678-692.

Saad, S., Selvadurai, S., Isnin, M. K. A., Basaruddin, N. H., \& Mansor, N. H. (2016). Sustainability of youth involment in oil palm sector. International Journal of Management and Applied Science, 2(10): 89-93.Sarawak Labour Ordinance 1952 (Malaysia).

Surianshah, W. N. S., Sieng, L. W., Salleh, M. N. M., Idris, S. H. M., \& Janor, H. (2020). Faktor mempengaruhi penglibatan belia dalam sektor perladangan kelapa sawit. International Journal of Management Studies, 28(1): 115-140.

Vietnam. (2021). COVID-19: Malaysia's Sarawak state reels from foreign workers' ban https://en.vietnamplus.vn/covid19-malaysias-sarawak-state-reels-from-foreignworkers-ban/187438.vnp.

Yoon, D. (2018). Rising unemployment among young people and improved employment policy: The case of South Korea. Economics and Socialogy 11(4): 246-264. 